\title{
АНАЛІЗ ОСОБИСТІСНИХ ЯКОСТЕЙ МЕДИЧНИХ СЕСТЕР НА РІЗНИХ ЕТАПАХ ПРОФЕСІЙНОГО СТАНОВЛЕННЯ
}

\author{
Я. Ю. Станишевська \\ ДЗ «Науково-практичний медичний реабілітаційно-діагностичний центр \\ МОЗ УКраїни» м. Костянтинівка
}

\begin{abstract}
У статті розглянуто динаміку формування та розвитку особистісних якостей медичних сестер. Психодіагностику проводили в групах працюючих медичних сестер та студентів випускного курсу сестринського відділення. Проведене дослідження підтвердило наявність відмінностей, що відбуваються в результаті професіоналізації, серед таких показників: обмежене мислення - розвинене мислення, морально незалежний - совісний, довірливий - підозрілий, прагматичний - мрійливий, наївний - проникливий, імпульсивний - організований, розслаблений - напружений, комунікативні здібності та стресостійкість.
\end{abstract}

\section{PERSONAL QUALITIES ANALYSIS FOR NURSES AT DIFFERENT STAGES OF PROFESSIONAL FORMATION}

\author{
Y. Y. Stanyshevska \\ SI «Scientific and Practical Medical Rehabilitation and Diagnostic center \\ of MPH of Ukraine", Kostyantynivka
}

Nurses' personal qualities formation and development was analyzed in the article. Psychodiagnostics measures were conducted in the groups of working nurses and nursing departments graduate students. The study demonstrates the existence of differences occurring as a professionalisation result due to following factors: limited - developed cogitation, morally independent - conscientious, confident suspicious, pragmatic - daydreamer, naive - perceptive, impulsive - organized, relaxed - tense, communication skills and stress-resistance.

Вступ. Затребуваною і актуальною сьогодні е проблема вивчення особистості медичної сестри, оскільки розкриття ключових параметрів особистісних якостей дозволять по-новому оцінити вже працюючих фахівців і сформувати оптимальний шлях розвитку, залежно від особистісних особливостей.

У літературних джерелах висвітлено дослідження психологічних якостей практикуючих медичних сестер залежно від рівня підготовки [1], особистісні, емоційні та мотиваційні якості медичних сестер [2], вивчалися особистісні особливості медичної сестри [3] та студентів середнього медичного навчального закладу, їх комунікативні та організаційні здібності, емпа-

(C) Я. Ю. Станишевська, 2015 тію [4], а також складено психологічний портрет медсестри, абітурієнта та випускника медичного училища з характеристикою вольової, комунікативної та емоційної сфер [5]. У сестринській професії дві останні відіграють особливу роль в системі «людина-людина», де неминучий вплив суб'єктів один на одного, а якість медичної допомоги визначається не тільки медичними знаннями, але й особистісними особливостями фахівця.

На думку дослідників, процес особистісного розвитку найбільш виражений на стадії професійного навчання [5], майбутні медичні працівники в більшості мають певний «комплект» якостей, що свідомо чи несвідомо впливає на вибір професії, тому саме в цей час необхідно забезпечити можливість формування професійно важливих якостей. 
Вивчення особливостей професійної діяльності медичних працівників має виняткову значущість, оскільки спрямовано на збереження, підтримку, розвиток здоров'я професіонала, його психологічної готовності до діяльності. Інтерес практичної охорони здоров'я до психологіч них аспектів професійної діяльності середніх медичних працівників пов'язаний також із проблемами ефективності, успішності функціонування медичного закладу, з проблемами індивідуального планування кар'ери професіонала.

Основна частина. Метою дослідження було обрано вивчення особистісних якостей медичних сестер на різних етапах професійного становлення.

Усього обстежено 90 осіб, з яких | групу склали 60 осіб - медичні сестри, які працюють у Державному закладі «Науково-практичний медичний реабілітаційно-діагностичний центр Міністерства охорони здоров'я України" (м. Костянтинівка, Донецька область) віком від 21 до 52 років, середній вік склав $(34,1 \pm 1,1)$ року, стаж практичної діяльності - $(13,7 \pm 1,1)$ року. До ІІ групи увійшли 30 студенток жіночої статі випускного курсу сестринського відділення Костянтинівського медичного училища в період проходження переддипломної практики віком від 20 до 27 років, середній вік - $(22,2 \pm 0,4)$ року.

Застосовували такі методи: спостереження, експертні оцінки, професіографія, психодіаг- ностика, статистичні розрахунки в програмі MedStat. Психодіагностичне дослідження проводили за допомогою таких методик: 16-факторний особистісний опитувальник (Р. Кеттелл); тест «Комунікативні та організаторські схильності» (В. В. Синявський та Б. А. Федоришин); діагностика рівня полікомунікативної емпатії (І. М. Юсупов); визначення стресостійкості та соціальної адаптації (Т. Холмс і Р. Раге); тест «Опитувальник комунікативної толерантності» (В. В. Бойко); методика локус контролю Дж. Роттера.

Проведений професіографічний аналіз діяльності медичних сестер дозволив сформувати перелік особистісних якостей, що є професійно важливими для цього виду праці (24 ocoбистісні якості).

Наступним етапом була експертна оцінка, яка дозволила визначити найбільш значущі, на думку експертів, професійно важливі якості медичних сестер: совісність, прагматичність, проникливість, організованість, розвинуті комунікативні та організаторські здібності, емпатійність, стресостійкість, толерантність, інтернальний локус контролю. В ролі експертів виступали 7 старших медичних сестер відділень віком від 34 до 52 років, середній стаж роботи - $(20,8 \pm 0,98)$ року.

Тестування за допомогою 16-факторного особистісного опитувальника дозволило встановити відмінності між групами обстежуваних (табл. 1).

Таблиця 1. Результати оцінки факторів особистості в досліджүваних групах, \%

\begin{tabular}{|c|l|c|c|}
\hline \multicolumn{1}{|c|}{ Фактор } & I група, $\mathrm{n}=60$ & II група, $\mathrm{n}=30$ \\
\hline \multirow{2}{*}{$\mathrm{B}$} & обмежене мислення & 13,3 & 23,3 \\
\cline { 2 - 4 } & розвинене мислення & 86,7 & 76,7 \\
\hline \multirow{2}{*}{$\mathrm{G}$} & морально незалежний & 5 & 30 \\
\cline { 2 - 4 } & совісний & 95 & 70 \\
\hline \multirow{2}{*}{$\mathrm{L}$} & довірливий & 91,7 & 90 \\
\cline { 2 - 4 } & підозрілий & $\mathbf{8 , 3}$ & 10 \\
\hline \multirow{2}{*}{$\mathrm{M}$} & прагматичний & 95 & 96,7 \\
\cline { 2 - 4 } & мрійливий & 5 & 3,3 \\
\hline \multirow{2}{*}{$\mathrm{N}$} & наївний & 25 & 50 \\
\cline { 2 - 4 } & проникливий & 75 & 50 \\
\hline \multirow{2}{*}{$\mathrm{Q}_{3}$} & імпульсивний & 6,7 & 13,3 \\
\cline { 2 - 4 } & організований & 93,3 & 86,7 \\
\hline \multirow{2}{*}{$\mathrm{Q}_{4}$} & розслаблений & 98,3 & 100 \\
\cline { 2 - 4 } & напружений & 1,7 & 0 \\
\hline
\end{tabular}

Проведена психодіагностика показала, що 54 опитуваних (95 \%) І групи мають дуже високий та високий рівень комунікативних здібностей, серед ІІ групи він встановлений у 6 осіб (20\%). Ці медичні сестри та студенти випускного курсу володіють вмінням знаходити спільну мову 3 різними людьми в різноманітних ситуаціях, здатністю індивідуального підходу до оточуючих, можуть стримувати себе, проявляти терпимість та природність при спілкуванні. Низький рівень та рівень

30 ISSN 2411-1597. МЕДСЕСТРИНСТВО. 2015. № 1 
нижче середнього отримали 4 особи $(6,7 \%) 3$ | групи та 23 особи $(76,7 \%) 3$ || групи, їх можна охарактеризувати як людей замкнутих, мовчазних, із загостреною самокритикою, що важко адаптуються до нововведень.

Організаторські здібності розподілилися таким чином: в І групі дуже високий рівень отримали у 54 осіб (90\%), в II групі - у 18 осіб (60\%), ці досліджувані ініціативні, у важливій або складній ситуації приймають самостійні рішення, відстоюють свою думку. Рівень нижче середнього та низький діагностовано в 4 осіб $(6,7 \%)$ з । групи та в 7 осіб (23,3\%) з II - ці особи не прагнуть до спілкування, почувають себе скуто в колективі, обмежують свої вербальні контакти.

Оцінювалась емпатія досліджуваних як здатність до співчуття, своєрідна психологічна «включеність» у світ переживань пацієнта. Результати тестування показали, що 50 осіб (83,3 \%) | групи та 27 осіб (90 \%) || групи мають середній (оптимальний) рівень емпатійності, що характерний для зрілих, професійно впевнених фахівців, які відрізняються високим комунікативним потенціалом, вмінням зберігати власну позицію і психологічну дистанцію, поряд з глибоким розумінням пацієнта і співпереживанням. Виявлено 7 осіб $(11,7 \%)$ з низьким рівнем емпатійності в I групі, 1 особа (3,3 \%) - в ІІ групі, ці медичні сестри та студенти випускного курсу зазнають труднощі у встановленні контактів 3 оточуючими, віддають перевагу усамітненим справам, а не роботі з пацієнтами. Високий рівень емпатії в | групі мають 3 особи (5 \%), в || - 2 особи $(6,7 \%)$, в даному випадку діагностовано афективний рівень емпатії, який свідчить про душевну ранимість, вразливість, безпричинне відчуття провини.

Вимоги, яким має відповідати емоційна сфера медичних працівників, досить суперечливі. Поряд 3 емпатійністю медичні сестри повинні бути і емоційно-стійкими. Високий ступінь опору стресу мають 49 осіб (81,7\%) І групи та 18 осіб (60\%) II групи, у цих досліджуваних ширший спектр застосовуваних дій для вирішення проблемних ситуацій, вони мають високий рівень самоконтролю. Граничний та низький ступінь виявлено у 11 осіб (18,3 \%) । групи та 12 осіб (40 \%) ІІ групи, що свідчить про те, що ці особи зазвичай незадоволені собою і обставинами, відчувають брак часу і постійне напруження, схильні до частих проявів агресивності.

У результаті психодіагностики комунікативної толерантності, що показує, якою мірою медична сестра сприймає суб'єктивно небажані, неприйнятні для неї індивідуальні особливості пацієнтів та співробітників, негативні якості, звички, чужі стилі поведінки та стереотипи мис- лення, встановлено переважання в I групі медсестер $з$ високим ступенем комунікативної толерантності - 51 особа (85\%), в II - 23 особи $(76,7 \%)$. Медична сестра та студент випускного курсу, які володіють високим рівнем комунікативної толерантності, урівноважені та сумісні 3 оточуючими. Сформованість толерантності забезпечує медичним працівникам цілісність особистісного та професійного розвитку. Низький ступінь толерантності зафіксовано у 1 особи $(1,7$ \%) з । групи, людина з такими показниками характеризуеться тенденціею сприймати свою професійну діяльність як джерело постійного стресу, відчуває труднощі при прийнятті рішень, у критичних ситуаціях губиться.

У І групі інтернальний локус контролю виявлено у 40 осіб (66,7\%), в II - у 20 осіб $(66,7 \%)$. Особи, які володіють інтернальним локусом контролю, більш впевнені в собі, послідовні й наполегливі в досягненні поставленої мети, врівноважені і меншою мірою схильні до синдрому емоційного вигорання. Екстернальний локус контролю притаманний 20 особам (33,3 \%) з І групи та 10 особам (33,3\%) - з ІІ. Досліджувані з екстернальним локусом контролю схильні приписувати наслідки своїх дій впливу обставин, відповідальність за свою діяльність вони покладають винятково на зовнішні умови.

3 метою встановлення достовірних відмінностей між особистісними якостями осіб I та II груп, які знаходяться на різних етапах професійного становлення, проводилося порівняння центральних тенденцій даних вибірок за критерієм Вілкоксона за допомогою програми MedStat (табл. 2).

Таким чином, статистично значущі відмінності для фактора В (обмежене мислення - розвинене мислення) говорять про оперативність розумових процесів, кмітливість, здатність швидко навчатися в опитуваних 3 I групи, в них досить високий рівень загальної культури, особливо вербальної. Студентів випускного курсу відрізняе конкретність і певна ригідність мислення.

Досліджувані I групи мають перевагу за фактором G (морально незалежний - совісний), в них більш розвинуте почуття обов'язку і відповідальності, вони усвідомлено дотримуються загальноприйнятих моральних правил і норм. Особам II групи притаманна імпульсивність, гнучкість відносно соціальних норм, свобода від їх впливу, іноді безпринципність і схильність до асоціальної поведінки.

Відмінність за фактором L (довірливий підозрілий) показала, що медичні сестри більш відкриті, терпимі, вільні від заздрощів, поступ- 
Таблиця 2. Порівняльна характеристика особистісних якостей в досліджүваних групах, $\operatorname{T} \operatorname{cep} . \pm m(p<0,05)$

\begin{tabular}{|c|c|c|c|}
\hline \multirow{2}{*}{ Показники } & \multicolumn{2}{|c|}{ T cep. $\pm \mathrm{m}$} & \multirow{2}{*}{$\begin{array}{c}\text { Значущість } \\
\text { відмінностей, p }\end{array}$} \\
\hline & I група, $\mathrm{n}=60$ & II група, $n=60$ & \\
\hline Обмежене мислення - розвинене мислення & $5,40 \pm 0,26$ & $4,40 \pm 0,29$ & $\mathrm{p}=0,038$ \\
\hline Морально незалежний - совісний & $8,10 \pm 0,15$ & $6,83 \pm 0,23$ & $\mathrm{p}<0,001$ \\
\hline Довірливий - підозрілий & $2,87 \pm 0,22$ & $4,10 \pm 0,30$ & $\mathrm{p}=0,002$ \\
\hline Прагматичний - мрійливий & $2,38 \pm 0,2$ & $3,37 \pm 0,26$ & $\mathrm{p}=0,002$ \\
\hline Наївний - проникливий & $6,30 \pm 0,19$ & $5,53 \pm 0,27$ & $\mathrm{p}=0,020$ \\
\hline Імпульсивний - організований & $7,80 \pm 0,21$ & $6,63 \pm 0,22$ & $\mathrm{p}<0,001$ \\
\hline Розслаблений - напружений & $3,68 \pm 0,22$ & $4,60 \pm 0,30$ & $\mathrm{p}=0,019$ \\
\hline Комунікативні здібності & $0,99 \pm 0,02$ & $0,73 \pm 0,04$ & $\mathrm{p}<0,001$ \\
\hline Стресостійкість & $132,20 \pm 11,41$ & $171,00 \pm 17,75$ & $\mathrm{p}=0,047$ \\
\hline
\end{tabular}

ливі, а студентам випускного курсу імпонує обережність, егоцентричність та настороженість відносно оточуючих.

Фактор М (прагматичний - мрійливий) характеризуе I групу як професіоналів із високою швидкістю вирішення практичних завдань, прозаїчних, орієнтованих на зовнішню реальність, а опитувані 3 || групи мають розширену уяву, поглинені внутрішніми ілюзіями, оперують абстрактними поняттями.

Фактор N (наївний - проникливий) характеризує медичних сестер як дипломатичних, емоційно-витриманих, проникливих спеціалістів, які вміють знаходити вихід зі складних ситуацій, а студенти випускного курсу більш відверті, наївні, безпосередні та емоційні.

Фактор $\mathrm{Q}_{3}$ (імпульсивний - організований) є важливішим для прогнозування успішності діяльності та дозволив встановити, що медичні сестри бережуть соціальну репутацію - їм властива тенденція до емоційного та поведінкового контролю, противагу складають особи II групи, діяльність яких невпорядкована та імпульсивна.

Дослідження фактора $\mathrm{Q}_{4}$ (розслаблений напружений) дозволило встановити, що медичні сестри схильні до розслабленості, врівноваженості, задоволеності наявним, а II група характеризуеться оптимальним емоційним тонусом. Показники за обома вибірками характерні для осіб з невисоким рівнем мотивації досягнення.

Як видно з таблиці 2, відмінності між групами за середніми показниками комунікативних здібностей вказують, що досліджувані І групи мають більш розвинені навички спілкування, ніж студенти випускного курсу.

За результатами дослідження можна стверджувати, що у практикуючих медичних сестер ступінь стресостійкості достовірно вищий, що зумовлено формуванням та розвитком опору стресовим чинникам у процесі професійної діяльності.

Висновки. 1. На середній медичний персонал лягає основне комунікативне навантаження, яке припускає не тільки спілкування з різними категоріями партнерів, а й забезпечення функціонування лікувального процесу як соціальної системи, тому до особистісних якостей медичних сестер висуваються відповідні вимоги: високий рівень комунікативних здібностей, середній рівень полікомунікативної емпатії та високий рівень комунікативної толерантності.

2. За результатами дослідження встановлено наявність достовірних відмінностей між особистісними якостями працюючих медичних cестер та випускників сестринського відділення медучилищ: обмежене мислення - розвинене мислення - $p=0,038$, морально незалежний совісний - $p<0,001$, довірливий - підозрілий $p=0,002$, прагматичний - мрійливий $-p=0,002$, наївний - проникливий - $p=0,020$, імпульсивний - організований - $p<0,001$, розслаблений - напружений - $p=0,019$, комунікативні здібності - $p<0,001$, стресостійкість $-p=0,047$.

3. Результати дослідження дозволяють стверджувати про існування відмінностей між особистісними якостями медичних сестер та студентів випускного курсу сестринського відділення на різних етапах професійного становлення. Ці відмінності можуть бути пов'язані зі сформованістю системи професійної діяльності у медичних сестер та відсутністю досвіду праці у випускників.

4. Дослідження особистісних якостей медичних сестер у процесі та після закінчення навчання, а також при прийомі на роботу та впродовж професійної кар'ери є необхідним засобом для прогнозування та формування готовності працівника до виконання професійної діяльності. 


\section{ЛITEPATУРА}

1. Хетагурова А. К. Особенности личностных качеств практикующих медицинских сестер с базовойи углубленной профессиональной подготовкой / А. К. Хетагурова, В. В. Морозов / / Сестринскоедело. - 2005. № 7. - C. 16-18.

2. Морозов В.В.Изменение психологических качеств практикующих медицинских сестер в условиях реформирования сестринского образования / В.В. Морозов // Сестринское дело. - 2005. - № 7. - С. 32-34.

3. Профиль работы, личностные особенностии эмоциональное здоровье медицинской сестры /
[Л. Т. Баранская, И. О. Елькин, Н. В. Гафароваидр.] // Медицинская помощь. - 2008. - № 1. - С. 45-47.

4. Рудыкина А. А. Экспериментальное исследование эмпатических способностей студентов медицинского колледжа - будущих медицинских сестер / А. А. Рудыкина, Г. С. Остапенко, Р. И. Остапенко // Современные научные исследования и инновации. - 2014. № 8. - C. 12-15.

5. Нехайчик Е. А. Психологический портрет медсестры, абитуриентаивыпускника медицинского училища / Е. А. Нехайчик / / Медицинская сестра. - 2004. - № 4. C. 35-39.

Отримано 24.12.14 